\title{
WIJSMAN LACUNARY INVARIANT STATISTICAL CONVERGENCE FOR TRIPLE SEQUENCES VIA ORLICZ FUNCTION
}

\author{
Mualla Birgül Huban* AND Mehmet GÜRdAl
}

Abstract. In this paper, we generalized the Wijsman lacunary invariant statistical convergence of closed sets in metric space by introducing the Wijsman lacunary invariant statistical $\widetilde{\phi}$ convergence for the sets of triple sequences. We introduce the concepts of Wijsman invariant $\widetilde{\phi}$-convergence, Wijsman invariant statistical $\widetilde{\phi}$-convergence, Wijsman lacunary invariant $\widetilde{\phi}$-convergence, Wijsman lacunary invariant statistical $\widetilde{\phi}$-convergence for the sets of triple sequences. In addition, we investigate existence of some relations among these new notations for the sets of triple sequences.

Mathematics subject classification (2010): 40A05, 40C05, 40D25.

Keywords and phrases: Triple sequence, Orlicz function, lacunary sequence, triple statistical convergence, Wijsman convergence.

\section{REFERENCES}

[1] B. Altay And F. BAşAR, Some new spaces of double sequences, J. Math. Anal. Appl., 309 (1) (2005), 70-90.

[2] M. Baronti And P. PAPInI, Convergence of sequences of sets, In: Methods of functional analysis in approximation theory, Birkhauser-Verlag, Basel, ISNM 76 (1986), 133-155.

[3] F. BAŞAR, Summability Theory and its Applications, Bentham Science Publishers, İstanbul, 2012.

[4] A. Esi And M. N. ÇATAlBAŞ, Almost convergence and triple sequences, Glob. J. Math. Anal., 2 (1) (2014), 6-10.

[5] A. ESI AND E. SAVAŞ, On lacunary statistically convergent triple sequences in probabilistic normed space, Appl. Math. Inf. Sci. 9 (5) (2015), 2529-2534.

[6] H. FAST, Sur la convergence statistique, Colloq. Math., 2 (1951), 241-244.

[7] J. A. FRIDY, On statistical convergence, Analysis (Munich) 5 (1985), 301-313.

[8] M. GÜRDAL, Some types of convergence, Doctoral Dissertation, S. Demirel Univ., Isparta, 2004.

[9] M. GÜRDAL AND M. B. HuBAn, On $\mathscr{I}$-convergence of double sequences in the topology induced by random 2 -norms, Mat. Vesnik 66 (1) (2014), 73-83.

[10] M. GÜRDAL And M. B. HubAn, Statistical convergence and $C^{*}$-operator algebras, Theory Appl. Math. Comput. Sci., 7 (2) (2017), 41-50.

[11] M. GÜRdal And S. Pehlivan, The statistical convergence in 2-Banach spaces, Thai J. Math., 2 (1) (2004), 107-113.

[12] M. GÜRdal And S. Pehlivan, Statistical convergence in 2-normed spaces, Southeast Asian Bull. Math., 33 (2) (2009), 257-264.

[13] M. B. HubAN, M. GÜRdAl, E. SAVAŞ, $\mathscr{I}$-statistical limit superior and $\mathscr{I}$-statistical limit inferior of triple sequences, 7th International Conference on Recent Advances in Pure and Applied Mathematics (ICRAPAM2020), Proceeding Book of ICRAPAM (2020), 42-49.

[14] M. Murs AleEn And F. BAŞAR, Sequence Spaces: Topics in Modern Summability Theory, CRC Press, Taylor \& Francis Group, Series: Mathematics and Its Applications, Boca Raton, London, New York, 2020.

[15] M. Mursaleen And O. H. H. Edely, On the invariant mean and statistical convergence, Appl. Math. Lett., 22 (11) (2009), 1700-1704. 
[16] M. Murs aleen And O. H. H. Edely, Statistical convergence of double sequences, J. Math. Anal. Appl., 288 (2003) 223-231.

[17] A. A. NAbIEV, E. Savaş AND M. GÜRdal, Statistically localized sequences in metric spaces, J. Appl. Anal. Comput. 92 (2019) 739-746.

[18] F. NURAY AND B. E. RHOADES, Statistical convergence of sequences of sets, Fasc. Math., 49 (2012), 87-99.

[19] F. NURAY AND U. Ulusu, Lacunary invariant statistical convergence of double sequences of sets, Creat. Math. Inform., 28 (2) (2019), 143-150.

[20] F. NURAY, U. Ulusu AND E. DÜNDAR, Lacunary statistical convergence of double sequences of sets, Soft Comput., 20 (7) (2016), 2883-2888.

[21] R. F. PATTERSON AND E. SAVAŞ, Lacunary statitistical convergence of double sequences, Math. Commun., 10 (2005), 55-61.

[22] M. M. RaO AND Z. D. Ren, Applications of Orlicz, spaces, Marcel Dekker Inc. 2002.

[23] A. ŞAhiner, M. GÜRDAL AND F. K. DÜDEN, Triple sequences and their statistical convergence, Selçuk J. Appl. Math. 8 (2) (2007), 49-55.

[24] R. SAVAŞ, Multiple $\lambda \mu$-statistically convergence via $\widetilde{\phi}$-functions, Math. Methods Appl. Sci., doi:10.1002/mma.7027 (2020), 1-8.

[25] E. SaVAŞ AND S. Debnath, Lacunary statistical $\phi$-convergence, Note Mat., 39 (2) (2019), 111-119.

[26] E. SAVAŞ AND F. NURAY, On $\sigma$-statistically convergence and lacunary $\sigma$-statistically convergence, Math. Slovaca, 43 (3) (1993), 309-315.

[27] P. SCHAEFER, Infinite matrices and invariant means, Proc. Amer. Math. Soc., 36 (1) (1972), $104-110$.

[28] H. Steinhaus, Sur la convergence ordinaire et la convergence asymptotique, Colloq. Math., 2 (1951), 73-74.

[29] U. Ulusu AND F. NURAY, $\mathscr{I}$-lacunary statistical convergence of sequences of sets, Progress in Applied Mathematics, 4 (2) (2012), 99-109.

[30] R. A. Wijsman, Convergence of sequences of convex sets, cones and functions, Bull. Amer. Math. Soc., 70 (1) (1964), 186-188. 